\title{
Influence of Wood Physical Properties on Charcoal from Eucalyptus spp.
}

\author{
Fernando Wallase Carvalho Andrade ${ }^{1,2}$, Mario Tomazello Filho ${ }^{3}$, \\ Victor Hugo Pereira Moutinho ${ }^{1}$
}

\begin{abstract}
${ }^{1}$ Instituto de Biodiversidade e Florestas - IBEF, Universidade Federal do Oeste do Pará - UFOPA, Santarém/PA, Brasil ${ }^{2}$ Faculdade de Ciências Agronômicas - FCA, Universidade Estadual Paulista - UNESP, Botucatu/SP, Brasil ${ }^{3}$ Escola Superior de Agricultura "Luiz de Queiroz" - ESALQ, Universidade de São Paulo - USP, Piracicaba/SP, Brasil
\end{abstract}

\begin{abstract}
The use of wood in the form of charcoal for energy production, has great economic importance in Brazil. In this context, the study of variables and mechanisms that affect charcoal quality is essential. The present study aimed to verify the influence of some physical properties of Eucalyptus wood on the quality and yield of the produced bioreducer. We used three commercial Eucalyptus clones, cultivated for use in the steel industry, determining wood density and shrinkage, density and immediate chemistry of the charcoal produced and the charcoal gravimetric yield. The data was submitted to Pearson's correlation analysis. Correlations between wood density and apparent charcoal density as well as charcoal ash content were observed. All clones presented characteristics suitable for the production of charcoal for the steel industry, with emphasis on the hybrid E. urophylla x E. grandis.
\end{abstract}

Keywords: steel charcoal, E. urophylla x E. grandis, charcoal properties, wood density. 


\section{INTRODUCTION}

In 2016, the use of wood in the domestic energy supply contributed $8.0 \%$ to the Brazilian energy matrix (Brasil, 2017), presenting high renewable and productive potential, with highly competitive costs in the national electric sector compared to hydroelectric and fuel oil plants (Vilela et al., 2014). In this context, the use of charcoal is highlighted due to the significant demand for this material in the Brazilian steel sector, where it is used as a bioreducer.

Brazil is a model country and the world leader in charcoal production and use as a bioreducer for iron ore in pig iron production (Morello, 2015). In 2015, annual charcoal production was 6.187 million tons (FAO, 2017), coming largely from carbonisation of forests planted with the genus Eucalyptus, which is widely used in Brazil given its high productivity and wide range of applications in forest based industries, as well as for decreasing pressure on native forests (Stanturf et al., 2013).

Scientific and technological changes have led to advances in the management and genetic improvement of this genera, resulting in increased forest productivity and gains in wood quality and homogeneity, transforming Brazil into the largest centre of forest production on the planet, with an average of $36 \mathrm{~m}^{3} \mathrm{ha}^{-1}$ year $^{-1}$ of eucalyptus forests planted (Colodette et al., 2014; IBÁ, 2016).

In addition to productivity, the differences in chemical, physical and morphological wood composition should also be considered for charcoal production, as they can affect the characteristics of the final product (Trugilho \& Silva, 2001). The variability of charcoal characteristics, such as lignin content and its sirigil/guaiacyl relation, basic density, diameter of the piece used in the carbonisation process and initial humidity, modify charcoal quality and yield (Soares et al., 2014; Costa et al., 2014; Soares et al., 2015; Araújo et al., 2016).

A range of wood characteristics must be considered in the production of bioreducers. However, basic density is an essential criterion in tree selection, as it is directly proportional to charcoal density and solid gravimetric yield (Pereira et al., 2012; Moutinho et al., 2016). Among the desirable physical characteristics, the steel industry requires that the apparent density of charcoal be as high as possible $\left(>0.300 \mathrm{~g} \mathrm{~cm}^{-3}\right)$, and that it have high mechanical resistance and low humidity values. In terms of chemical characteristics, charcoal with a high lignin content and a low siringil/guaiacyl ratio, low ash content $(<1 \%)$, average volatile materials content $(<25 \%)$, high calorific value $\left(>7,500 \mathrm{kcal} \mathrm{kg}^{-1}\right)$ and high fixed carbon content (> 75\%) (Trugilho et al., 2005; Pereira et al., 2012, 2013) is preferred. Understanding the direct influence of the properties of wood as a raw material, the investigation of correlations between the source material and the final product is crucial.

Due to the economic importance of charcoal as a bioreducer and aiming to provide additional information about different Eucalyptus hybrids used in the steel industry in Brazil, this study verified the influence of physical wood properties on the quality and yield of charcoal produced, indicating the most appropriate clones for the production of charcoal used in the steel industry.

\section{MATERIAL AND METHODS}

We collected trees of Eucalyptus urophylla, Eucalyptus urophylla $x$ Eucalyptus grandis and (E. camaldulensis $x$ E. grandis) $x$ Eucalyptus urophylla from an approximately 6-year-old commercial plantation, located in the Alto do Jequitinhonha region in the state of Minas Gerais, $1^{\circ} 41^{\prime} 38^{\prime \prime S}$ and $42^{\circ} 31^{\prime} 07^{\prime \prime} \mathrm{O}$, at 1,070 m above sea level. The trees were produced through genetic improvement programs by steel companies. Average annual temperature in the region is $21^{\circ} \mathrm{C}$, with accumulated precipitation of $1,166 \mathrm{~mm}$.

Three trees of each clone were randomly selected and cut in the field, and we collected discs with a thickness of $15 \mathrm{~cm}$ at $0,25,50,75$ and $100 \%$ of commercial height, apart from an extra disk at $1.30 \mathrm{~m}$ from ground height (DBH).

From each disk, we collected samples in marrow-bark direction (radial), as shown in Figure 1. The number of samples varied according to the diameter of each disk. On average, 27 samples per tree were used for analysis.

The samples $\left(20 \times 20 \times 40 \mathrm{~mm}^{3}\right)$, obtained in tangential, radial and longitudinal directions, were immersed in water until saturated, using a vacuum recipient, and then kiln-dried until constant mass was achieved. For each sample, we determined the basic density and the linear and volumetric shrinkage, adapting the standard NBR 7190 (ABNT, 1997). 
The anisotropy coefficient was calculated as the ratio between tangential and radial shrinkage.

The same samples used for the determination of physical wood properties, previously kiln-dried, were used for carbonisation to increase the reliability of the results. Carbonisations were conducted in an electric muffle furnace with a maximum carbonisation temperature of $400^{\circ} \mathrm{C}$ and an average heat rate of $1^{\circ} \mathrm{C}$ $\mathrm{min}^{-1}$, remaining stable for a period of 60 minutes.

Gravimetric charcoal yield was determined relating the mass of charcoal produced with the mass of the dried wood samples (Equation 1):

$G Y C=(C m / D w m) * 100$

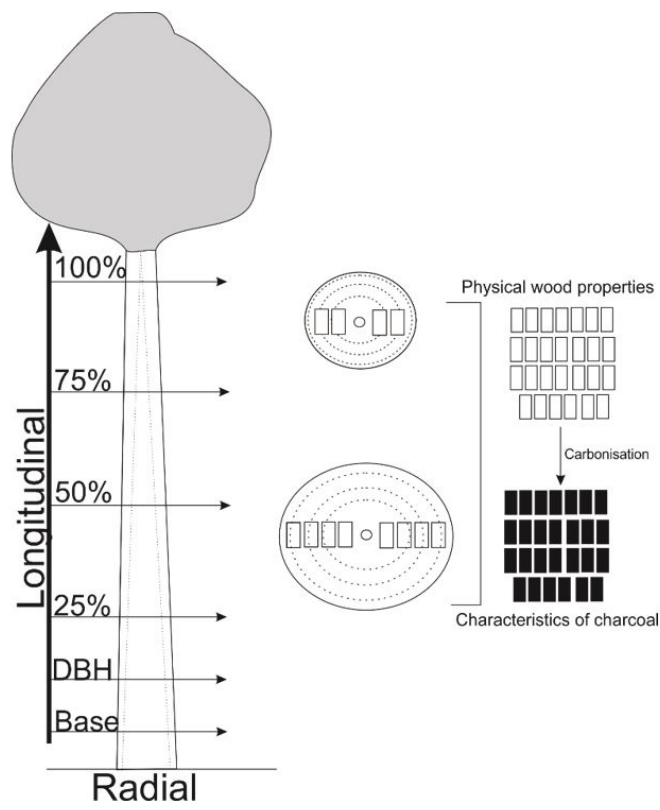

Figure 1. Longitudinal positions of wood discs and radial position of the samples. where: GYC = gravimetric charcoal yield (\%); $\mathrm{Cm}=$ charcoal mass; Dwm $=$ dried mass of wood sample.

Apparent relative density (ARD) of charcoal was determined using dried charcoal mass and volume by immersion in mercury, according to the adaptation of the standard NBR 7190 (ABNT, 1997).

Chemical analysis of the charcoal produced was performed on carbonized samples, using six repetitions per tree (one for each longitudinal position). Volatile level (VL), ash content (AC) and fixed carbon content (FCC) in the dried base were determined according to the procedure established in the standard D1762-84 (ASTM, 2007).

To determine correlations between wood and charcoal density, we used a linear regression in a specific manner (for each treatment) and in a general way (without distinguishing between treatments). We determined the coefficient of Pearson's correlation $(\mathrm{p}=0.05)$ to measure the association between the wood and charcoal variables, considering the data without distinguishing between treatments.

For all statistical analyses, we used the software package R, version 2.11.0 (R Development Core Team, 2011), and the agricolae package (Mendiburu, 2013). When differences were significant via variance analysis, we applied the Scott Knott test of multiple comparison at $5 \%$ probability.

\section{RESULTS AND DISCUSSION}

The basic density of the studied clones varied between 0.567 and $0.696 \mathrm{~g} \mathrm{~cm}^{-3}$, with differences being statistically significant (Table 1 ). The values found by Pádua et al. (2015), when working with 5.5-year-old Eucalyptus grandis $x$ Eucalyptus urophylla, are similar to those

Table 1. Average values of physical wood properties of the three tree clones used in this study.

\begin{tabular}{|c|c|c|c|c|c|c|}
\hline \multirow[b]{2}{*}{ Clone } & \multirow{2}{*}{$\begin{array}{c}\text { Basic } \\
\text { Density } \\
\left(\mathrm{g} \mathrm{cm}^{-3}\right)\end{array}$} & \multicolumn{4}{|c|}{ Shrinkage (\%) } & \multirow[b]{2}{*}{ A.C. } \\
\hline & & Tangential & Radial & Axial & Volumetric & \\
\hline 1. E. urophylla & $0.658 \mathrm{~b}$ & $6.821 .3 \mathrm{~b}$ & $4.84 \mathrm{~b}$ & $0.04 \mathrm{~b}$ & $12.17 \mathrm{~b}$ & $1.45 \mathrm{~b}$ \\
\hline Standard error & \pm 0.014 & \pm 0.267 & \pm 0.217 & \pm 0.015 & \pm 0.439 & \pm 0.068 \\
\hline $\begin{array}{l}\text { 2. (E. camaldulensis } \mathrm{x} \text { E. grandis) } \mathrm{x} \\
\text { E. urophylla }\end{array}$ & $0.567 \mathrm{c}$ & $8.90 \mathrm{a}$ & $5.81 \mathrm{a}$ & $0.44 \mathrm{a}$ & $15.22 \mathrm{a}$ & $1.65 \mathrm{~b}$ \\
\hline Standard error & \pm 0.010 & \pm 0.547 & \pm 0.328 & \pm 0.152 & \pm 0.707 & \pm 0.133 \\
\hline 3. E. urophylla $\mathrm{x}$ E. grandis & $0.696 \pm \mathrm{a}$ & $8.92 \pm \mathrm{a}$ & $4.53 \mathrm{~b}$ & $0.14 \mathrm{~b}$ & $13.93 \mathrm{a}$ & $2.11 \mathrm{a}$ \\
\hline Standard error & \pm 0.013 & \pm 0.556 & \pm 0.280 & \pm 0.050 & \pm 0.714 & \pm 0.157 \\
\hline
\end{tabular}

A.C. $=$ anisotropy coefficient. Averages followed by the same letter in the column did not differ significantly at $5 \%$ probability. 
for (E. camaldulensis $x$ E. grandis) $x$ Eucalyptus urophylla clones, while Rosa et al. (2017), studying seven-year-old Eucalyptus urophylla $x$ Eucalyptus grandis clones, found lower values $\left(0.472 \mathrm{~g} \mathrm{~cm}^{-3}\right)$ compared to those in the present study.

In terms of wood shrinkage (Table 1), the values observed were comparable to those found by Gonçalves et al. (2009), who worked with 5.8-year-old progenies of Eucalyptus, but lower than those found by Oliveira et al. (2010), who found values of $15.3,7.9$ and $25.6 \%$ for tangential, radial and volumetric shrinkage, respectively, when studying 16-year-old Eucalyptus urophylla clones. The shrinkage values for Eucalyptus wood tended to increase according to the age of the material, due to the increase in density and thickness of the fibre wall and the content and composition of extractives (Hernandez 2007; Sette et al., 2012).

According to Oliveira et al. (2010), although volumetric shrinkage is important, what defines wood as an anisotropic material is the unequal dimensional shrinkage/swelling along the orthogonal axes, mainly tangential and radial, resulting in the anisotropy coefficient, which is the ratio between the values of the two plans. For charcoal production, the lower the wood coefficient, the lower the tendency towards defects and cracks during the drying step in the carbonisation process, which can positively affect the mechanical properties and the friability of the charcoal produced.

Therefore, considering the anisotropy coefficient values, the (E. camaldulensis $x$ E. grandis) $x$ E. urophylla clones presented lower values and did not differ significantly from each other, while the E. urophylla $x$ E. grandis clone showed a significantly higher value.

Based on Pearson's correlation coefficients (Table 2), some physical wood properties showed significant correlations.
The higher values of tangential shrinkage lead to a higher anisotropy coefficient. According to Durlo \& Marchiori (1992), this directly proportional relation can be explained by the higher concentration of cells with thick walls in the tangential plan, making the radial plan follow its dimensional movement. Consequently, the anisotropy coefficient, which is the result of this interaction, tends to increase.

Volumetric shrinkage can be conceptualised as the sum of linear shrinkages, which obviously results in a significant correlation between variables. Therefore, we did not apply the correlation test with these variables.

As for the significant correlation between basic density and volumetric shrinkage, it is important to mention that shrinkage is nothing more than the physical response of the wood to the chemical phenomenon of microfibrils approaching the S2 layer due to the impregnated water outlet. The amount of microfibrils increases with the density and thickness of the cell wall. The proportional increase of free hydroxyl groups increases the hygroscopicity of the wood, and consequently, its volumetric changes.

Based on our results (Table 1), the E. urophyllax E. grandis clone, which presented the highest density, also presented the highest volumetric shrinkage, corroborating with the correlation observed (Table 2). However, this was not observed for the (E. camaldulensis $\mathrm{x}$ E. grandis) $\mathrm{x}$ E. urophylla clone, which also showed a high volumetric shrinkage, albeit with a lower value of basic density between the three evaluated clones.

This asymmetric behaviour between clones corroborates the findings of Neves et al. (2011), which showed that basic density should not be evaluated in isolation. According to Pelozzi et al. (2012) the main component that influences these dimensional variations is the microfibril angle. In this context, future studies

Table 2. Pearson's correlation coefficients for physical properties of the evaluated clones.

\begin{tabular}{|c|c|c|c|c|c|c|}
\hline \multirow{2}{*}{ Variable } & \multicolumn{4}{|c|}{ Shrinkage } & \multirow{2}{*}{$\begin{array}{c}\text { Basic } \\
\text { Density }\end{array}$} & \multirow{2}{*}{ A.C. } \\
\hline & Tangential & Radial & Axial & Volumetric & & \\
\hline Tangential shrinkage & 1 & & & & & \\
\hline Radial shrinkage & 0.127 & 1 & & & & \\
\hline Axial shrinkage & 0.151 & $0.392^{*}$ & 1 & & & \\
\hline Volumetric shrinkage & ---- & ---- & ---- & 1 & & \\
\hline Basic density & -0.190 & -0.161 & -0.141 & $-0.249^{\star}$ & 1 & \\
\hline Anisotropy coefficient & $0.679^{*}$ & $-0.550^{*}$ & -0.014 & $0.331^{*}$ & -0.029 & 1 \\
\hline
\end{tabular}

A.C. $=$ anisotropy coefficient; ${ }^{*}=$ significant at $5 \%$ probability. 
should include the microfibril angle as a variable to be evaluated in the correlations, as the extractive content can also influence the sorption and dimensional movement of wood, conferring a higher hygroscopic stability on pieces due to the hydrophobic effect inside the cell walls, as shown by Hernandez (2007).

In terms of relative charcoal density, the E. urophylla $x$ E. grandis clone differed significantly from the others (Table 3). The observed values for this variable for all clones were lower than the ones found by Trugilho et al. (2001), who worked with seven-year-old Eucalyptus grandis clones under similar carbonisation conditions and obtained a value of $0.44 \mathrm{~g} \mathrm{~cm}^{-3}$ for ARD, $36.8 \%$ for GYC and $79.5 \%$ for FCC. These values are higher than the ones found by Trugilho et al. (2005), who evaluated seven-year-old Eucalyptus hybrids, carbonised at $450^{\circ} \mathrm{C}$, at a heat rate of $1.6^{\circ} \mathrm{C} \mathrm{min}^{-1}$, and measured $0.31 \mathrm{~g} \mathrm{~cm}^{-3}$ for ARD, $40.2 \%$ for GYC and $67.97 \%$ for FCC.

In terms of charcoal gravimetric yield, the (Eucalyptus camaldulensis $\mathrm{x}$ Eucalyptus grandis) $x$ Eucalyptus urophylla clone presented higher values, with significant differences (Table 3). However, it also showed a significantly lower density, while the ash content (AC) was significantly higher when compared to the other evaluated clones, which can compromise both usable volume inside the blast furnace and the quality of the steel produced.

The E. urophylla clone presented intermediate values for the variable apparent density, with significantly lower charcoal density and fixed carbon values when compared to the E. urophylla $x$ E. grandis hybrid. Dias et al. (2016) found an apparent density value of $0.34 \mathrm{~g} \mathrm{~cm}^{-3}$ when working with $E$. grandis clones (final temperature $500^{\circ} \mathrm{C}$, with a heating rate of $1.67^{\circ} \mathrm{C}$ ).
The authors suggested that this variable can be affected both by the process and by the raw material.

The E. urophylla $x$ E. grandis clone presented the second highest charcoal yield (GYC); it also had the highest density and fixed carbon values. These parameters, according to Souza et al. (2016), are indicators of the bioreducer production quality.

These values are higher than those found by Arantes et al. (2013), who worked with six-year-old Eucalyptus grandis $x$ Eucalyptus urophylla clones of different diametric classes, carbonized at $450^{\circ} \mathrm{C}$ of temperature with a heat rate of $1.6^{\circ} \mathrm{C} \mathrm{min}{ }^{-1}$; these authors obtained a charcoal yield of $34 \%$. As the carbonisation parameters in our study differed in final temperature and heating rate of these authors, it is important to highlight that lower temperatures and heat rates, as observed in the present study, tend to increase both charcoal density and yield.

Basic wood density was positively and significantly correlated with apparent charcoal density (Table 4 ). This result is in agreement with the findings of Pereira et al. (2012), who studied different Eucalyptus clones and observed a direct influence of wood density on apparent charcoal density.

Pereira et al. (2012) states that although basic wood density is a quality index for wood, it cannot be used in isolation as a parameter to select clones for charcoal production. Gravimetric yield is an important parameter in charcoal production, however, it was not correlated with any of the wood variables. The increase of gravimetric yield depends on other factors, mainly the final temperature of the carbonisation process, and is also associated with higher lignin content and lower siringil/guaiacyl ratio of the wood (Gouvêa et al., 2015; Pereira et al., 2013).

Table 3. Gravimetric charcoal yield and charcoal properties of the three clones.

\begin{tabular}{lccccc}
\multicolumn{1}{c}{ Clones } & $\begin{array}{c}\text { ARD } \\
\left(\mathbf{g ~ c m}^{-3}\right)\end{array}$ & GYC (\%) & VL (\%) & AC (\%) & FCC (\%) \\
\hline 1. E. urophylla & $0.343 \mathrm{~b}$ & $33.74 \mathrm{c}$ & $35.2 \mathrm{a}$ & $1.1 \mathrm{~b}$ & $63.4 \mathrm{~b}$ \\
Standard error & \pm 0.006 & \pm 0.253 & \pm 0.898 & \pm 0.241 & \pm 0.933 \\
2. (E. camaldulensis $x$ E. grandis) $\mathrm{x}$ E. urophylla & $0.321 \mathrm{~b}$ & $38.99 \mathrm{a}$ & $33.5 \mathrm{a}$ & $1.9 \mathrm{a}$ & $64.1 \mathrm{~b}$ \\
Standard error & \pm 0.004 & \pm 0.300 & \pm 0.822 & \pm 0.259 & \pm 0.751 \\
\hline 3. E. urophylla $\mathrm{x}$ E. grandis & $0.371 \mathrm{a}$ & $35.68 \mathrm{~b}$ & $29.7 \mathrm{~b}$ & $1.1 \mathrm{~b}$ & $69.2 \mathrm{a}$ \\
Standard error & \pm 0.008 & \pm 0.402 & \pm 1.301 & \pm 0.110 & \pm 1.260 \\
\hline
\end{tabular}

ARD: apparent relative density; VL: volatile levels; AC: ash content; FCC: fixed carbon content; GYC: gravimetric yield in charcoal. Averages followed by the same letter in the same column did not differ significantly at $5 \%$ probability. 
The charcoal characteristic which most correlated with the physical properties of evaluated clones was ash content (AC), according to Table 4. The significant correlation indicates that denser wood with a higher tangential and volumetric shrinkage, will produce charcoal with a lower ash content, which is an important variable when using this product as a bioreducer, because bioreducers are incorporated into metallic alloys which makes them brittle (Trugilho \& Silva, 2001).

The results of the correlation analysis between basic wood density and apparent charcoal density for three Eucalyptus hybrids are presented in Figure 2.

Basic wood density can explain around $73 \%$ of the apparent density variation of charcoal, confirming

Table 4. Pearson's correlation coefficients for physical wood properties and charcoal characteristics evaluated in this experiment.

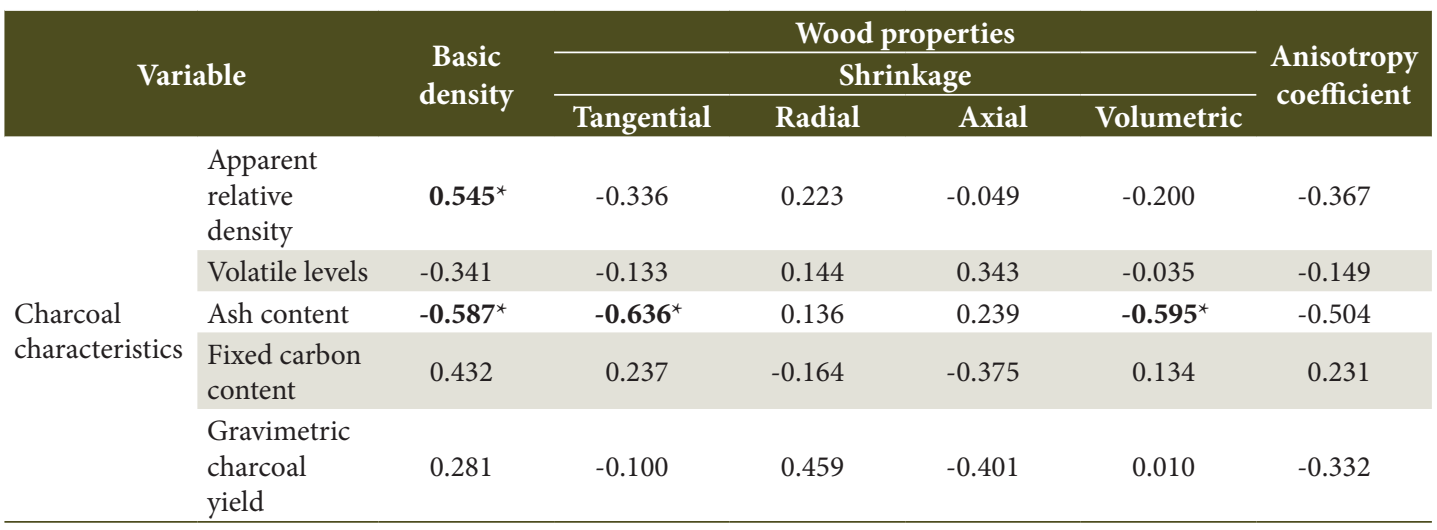

${ }^{*}=$ significant at $5 \%$ probability.
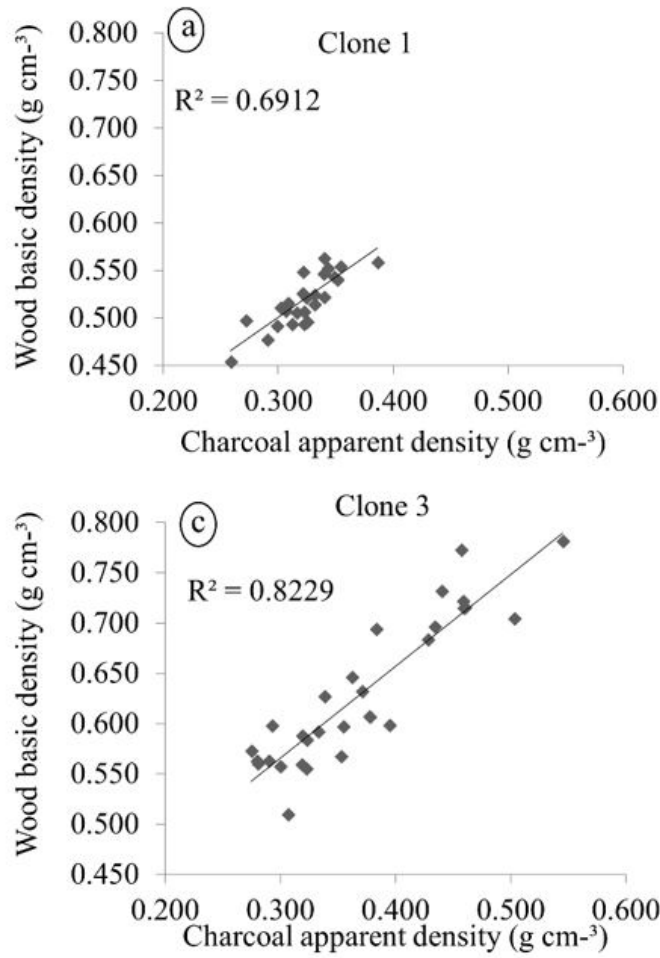
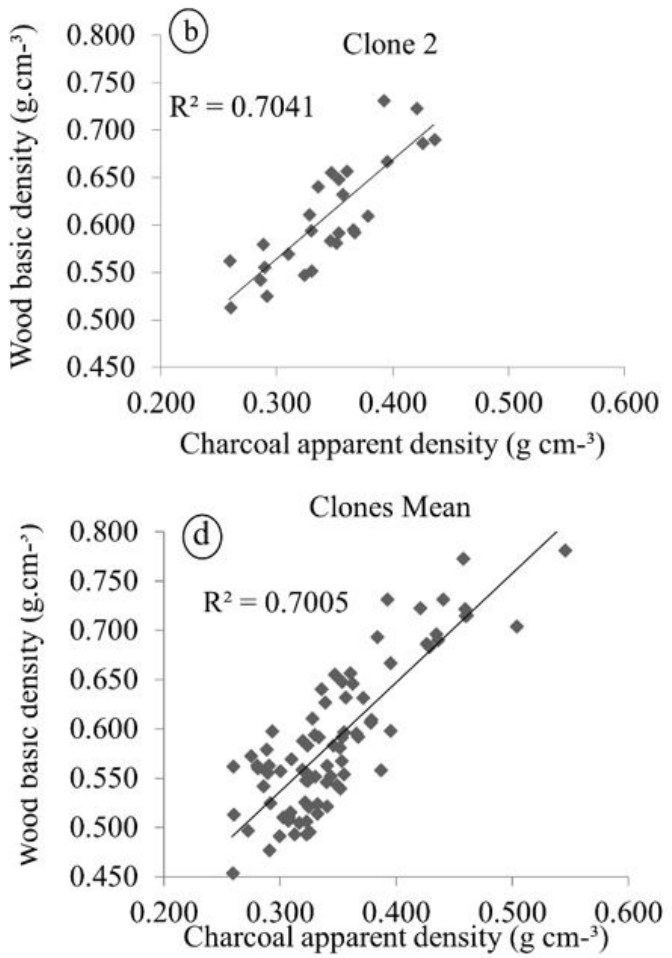

Figure 2. Relationship between basic wood density and the apparent density of charcoal from wood of Eucalyptus urophylla (a), Eucalyptus urophylla $x$ Eucalyptus grandis (b) and (Eucalyptus camaldulensis $x$ Eucalyptus grandis) $x$ Eucalyptus urophylla (c) and averaged across the three clones (d). 
the direct and positive ratio between these variables. For charcoal production, it is therefore advisable to select wood with a high basic density.

\section{CONCLUSIONS}

Basic wood density significantly influenced volumetric shrinkage of wood, the ash content and the apparent density of the charcoal.

All evaluated clones presented appropriate characteristics for the production of charcoal to be used in the steel industry, highlighting especially the E. urophylla $x$ E. grandis hybrid.

\section{ACKNOWLEDGEMENTS}

The authors wish to thank the Federal University of the West of Pará (UFOPA) and School of Agriculture Luiz de Queiroz (ESALQ) for support this research.

\section{SUBMISSION STATUS}

Received: 22 may, 2017

Accepted: 21 july, 2017

\section{CORRESPONDENCE TO}

\section{Fernando Wallase Carvalho Andrade}

Departamento de Ciência Florestal, Universidade Estadual Paulista - UNESP, Av. Dr. José Barbosa de Barros, 1780, Jd. Paraiso, CEP 18610-307, Botucatu, SP, Brasil e-mail: fernando.andrade@ufopa.edu.br

\section{REFERENCES}

American Society for Testing and Materials - ASTM. D1762-64: Standard method for chemical analyses of wood charcol. Phyladelphia: ASTM; 2007.

Arantes MDC, Trugilho PF, Silva JRM, Andrade CR. Características do carvão de um clone de Eucalyptus grandis W. Hill ex Maiden x Eucalyptus urophylla S. T. Blake. Cerne 2013; 19(3): 423-431.

Araújo ACC, Trugilho PF, Napoli A, Braga PPC, Lima RV, Protásio TP. Efeito da relação siringil/guaiacil e de fenóis derivados da lignina nas características da madeira e do carvão vegetal de Eucalyptus spp. Scientia Forestalis 2016; 44(110): 405-414.
Associação Brasileira de Normas Técnicas - ABNT. NBR 7190: Projeto de estruturas de madeira. Rio de Janeiro: ABNT; 1997.

Brasil. Ministério de Minas e Energia Balanço Energético Nacional. Relatório síntese ano base 2016 [online]. Rio de Janeiro: EPE; 2017 [cited 2017 July 12]. Available from: https://ben.epe.gov.br/benrelatoriosintese.aspx

Colodette JL, Gomes CM, Gomes FJ, Cabral CP. The Brazilian wood biomass supply and utilization focusing on eucalypt. Chemical and Biological Technologies in Agriculture 2014; 1(1): 1-8.

Costa TG, Bianchi ML, Protásio TP, Trugilho PF, Pereira AJ. Qualidade da madeira de cinco espécies de ocorrência no cerrado para produção de carvão vegetal. Cerne 2014; 21(2): 91-97.

Dias AF Jr, Costa DS Jr, Andrade AM, Oliveira E, Lana AQ, Brito JO. Quality of eucalyptus wood grown in Rio de Janeiro State for bioenergy. Floresta e Ambiente 2016; 23(3): 435-442.

Durlo MA, Marchiori JNC. Tecnologia da madeira: retratibilidade. Santa Maria: CEPEF/FATEC; 1992. 33 p. (Série técnica, no. 10).

Food and Agriculture Organization of the United Nations - FAO. FAOStat: ForeStat [online]. Rome: FAO; 2017. [cited 2017 May 3]. Available from: http://faostat.fao. org/site/626/default.aspx\#ancor

Gonçalves FG, Oliveira JTS, Lucia RMD, Nappo ML, Sartorio RC. Densidade básica e variação dimensional de um híbrido clonal de Eucalyptus urophylla x Eucalyptus grandis. Revista Árvore 2009; 33(2): 277-288.

Gouvêa AFG, Trugilho PF, Assis CO, Assis MR, Colodette JL, Gomes CM. Avaliação do efeito da relação siringila/ guaiacila da lignina de eucalipto na produção de carvão vegetal. Revista Ciência da Madeira 2015; 6(2), 71-78.

Hernandez RE. Swelling properties of hardwoods as affected by their extraneous substances, wood density, and interlocked grain. Wood and Fiber Science 2007; 39(1): 146-158.

Indústria Brasileira de Árvores - IBÁ. Relatório IBÁ 2016. São Paulo: Studio 113; 2016.

Mendiburu F. Agricolae: Statistical Procedures for Agricultural Research. R Package Version 1.1-4. USA: CRAN; 2013.

Morello TF. Carbon neutral merchant pig iron in Brazil: Alternatives that allow decoupling from deforestation. Energy for Sustainable Development 2015; 27: 93-104.

Moutinho VHP, Tomazello M, Brito JO, Ballarin AW, Andrade FWC. Influence of the wood physical properties on the charcoal physical and mechanical properties. Scientia Forestalis 2016; 44(111): 557-561.

Neves TA, Protásio TP, Couto AM, Trugilho PF, Silva VO, Vieira CMM. Avaliação de clones de Eucalyptus em 
diferentes locais visando à produção de carvão vegetal. Pesquisa Florestal Brasileira 2011; 31(68): 319-330.

Oliveira JTS, Tomazello M Fo, Fiedler NC. Avaliação da retratibilidade da madeira de sete espécies de Eucalyptus. Revista Árvore 2010; 34(5): 929-936.

Pádua FA, Trugilho PF, Thiersch CR, Vire NM, Silva JMS. Tamanho amostral para a estimativa da densidade básica em um clone híbrido de Eucalyptus sp. Revista do Instituto Florestal 2015; 27(1): 41-47.

Pelozzi MMA, Severo LTD, Calonego FW, Rodrigues PLM. Propriedades físicas dos lenhos juvenil e adulto de Pinus elliottii Engelm var. elliottii e Eucalyptus grandis Hill ex Maiden. Ciência Florestal 2012; 22(2): 305-313.

Pereira BLC, Carneiro ACO, Carvalho AMML, Colodete JL, Oliveira AC, Fontes MPF. Influence of chemical composition of Eucalyptus wood on gravimetric yield and charcoal properties. BioResources 2013; 8(3): 4574-4592.

Pereira BLC, Oliveira AC, Carvalho AMML, Carneiro ACO, Santos LC, Vital BR. Quality of wood and charcoal from Eucalyptus Clones for Ironmaster use. International Journal of Forestry Research 2012; (2012): 1-8. http:// dx.doi.org/10.1155/2012/523025.

R DEVELOPMENT CORE TEAM. R: A language and environment for statistical computing [online]. Vienna: R Foundation for Statistical Computing; 2011. [cited 2015 Dec 13]. Available from: http://www.R-project.org

Rosa TS, Trianoski R, Iwakiri S, Bonduelle GM, Souza HP. Utilização de Cinco Espécies de Eucalyptus para a Produção de Painéis OSB. Floresta e Ambiente 2017; 24: e20160049.

Sette RC Jr, Oliveira IR, Tomazelo Filho M, Yamaji FM, Laclau JP. Efeito da idade e posição de amostragem na densidade e características anatômicas da madeira de Eucalyptus grandis. Revista Árvore 2012; 36(6): 1183-1190.

Soares VC, Bianchi ML, Trugilho PF, Hofler J, Pereira AJ. Análise das propriedades da madeira e do carvão vegetal de híbridos de eucalipto em três idades. Cerne 2015; 21(2): 91-97.

Soares VC, Bianchi ML, Trugilho PF, Pereira AJ, Hofler J. Correlações entre as propriedades da madeira e do carvão vegetal de híbridos de Eucalipto. Revista Árvore 2014; 38(3): 543-549.

Souza ND, Amodei JB, Xavier CN, Dias AF Jr, Carvalho AM. Estudo de caso de uma planta de carbonização: avaliação de características e qualidade do carvão vegetal visando uso siderúrgico. Floresta e Ambiente 2016; 23(2): 270-277.

Stanturf JA, Vance ED, Fox TR, Kirst M. Eucalyptus beyond its native range: environmental issues in exotic bioenergy plantations. International Journal of Forestry Research 2013; (2013): 1-5. http://dx.doi.org/10.1155/2013/463030.

Trugilho PF, Silva DA. Influência da temperatura final de carbonização nas características físicas e químicas do carvão vegetal de jatobá (Hymenea courbaril L.). Scientia Agraria 2001; 2(1-2): 1-9.

Trugilho PF, Silva JRM, Mori FA, Tarcisio JL, Mendes LM, Mendes LFB. Yield and charcoal characteristics in relation of radial sampling position in Eucalyptus clones. Cerne 2005; 11(2): 178-186.

Trugilho PF, Tarcisio JL, Akira FM, Lino AL. Avaliação de clones de Eucalyptus para produção de carvão vegetal. Cerne 2001; 7(2): 104-114.

Vilela AO, Lora ES, Quintero QR, Vicintin RA, Souza TPS. A new technology for the combined production of charcoal and electricity through cogeneration. Biomass and Bioenergy 2014; 69: 222-240. 